\title{
WHAT ARE STATUES GOOD FOR? WINNING THE BATTLE OR LOSING THE BATTLEGROUND?
}

\begin{abstract}
Author:
A. Goodrich ${ }^{1}$

P. Bombardella ${ }^{1}$

\section{Affiliation:}

${ }^{1}$ School of Philosophy, NorthWest University, Potchefstroom Campus
\end{abstract}

\section{Correspondence to:}

André Goodrich

\section{Postal Address:}

Faculty of Arts

Potchefstroom Campus, NorthWest University

Potchefstroom 2531

Email:

Andre.goodrich@nwu.ac.za

\section{Correspondence to:}

Pia Bombardella

\section{Postal Address:}

Faculty of Arts

Potchefstroom Campus, NorthWest University

Potchefstroom 2531

Email:

Pia.bombardella@nwu.ac.za

Dates:

15 Dec. 2016

How to cite this article: Goodrich, A \& Bombardella, P, 2016. "What are statues good for? Winning the battle or losing the battleground?". KOERS - Bulletin for Christian Scholarship, 81(3). Available at: https://doi.org/10.19108/ KOERS.81.3.2272

\section{Copyright:}

(c) 2016. The Author(s).

Published under the Creative Commons Attribution License.
In South Africa the practice of toppling statues is as old as the practice of erecting them. The most recent episode in this history began in 2015 with the Rhodes Must Fall campaign at the University of Cape Town, from where it rapidly spread to sites throughout South Africa. Confronted with the fact that $97 \%$ of South Africa's 3500 declared heritage sites related to white values and experiences at the end of the apartheid era and that there has been little progress towards crafting a more representative heritage landscape, one cannot dispute the Rhodes Must Fall assertion that South African statues anachronistically honour the leading figures of South Africa's colonial and apartheid past. Observing that public debate around the statues was rapidly polarised into two camps, those who would defend the statues and those who would destroy them, this paper argues that neither option sufficiently addresses the multiple meanings of statues. By examining the changing public-history discourses of the 2oth century we propose a third approach grounded in post humanist arguments about the limitation of critique and the promise of care as an ethical, affective and practical pursuit. We argue that this post humanist approach to the question of what to do with statues in South Africa is capable of transforming them from fetishised objects of offence or of heritage into points around which new publics can gather and through which the historical ontology of contemporary power dynamics can be accessed, interrogated and acted upon in order to build new forms of citizenship.

KEYWORDS: Fetish, post humanism, heritage, statues, public, Rhodes must fall.

In Suid-Afrika is die praktyk van standbeelde omgooi net so oud soos die praktyk om hulle op te rig. Die mees onlangse episode in hierdie geskiedenis het in 2015 in Kaapstad begin met die Rhodes Must Fall veldtog by die Universiteit van Kaapstad en daarvandaan het dit vining versprei na plekke dwarsoor Suid-Afrika. Gesien in die lig van feit dat teen die einde van die apartheidera $97 \%$ van Suid-Afrika se 3500 erfenisplekke verwant was aan blanke waardes en ervaringe en dat daar min vordering was met die daarstelling van 'n meer verteenwoordigende erfenislandskap, kan mens nie wegkom van Rhodes Must Fall stelling dat Suid-Afrikaanse beelde ' $n$ anachronistiese verering is van die leidende figure van Suid-Afrika se koloniale en apartheidsverlede. Gegewe dat die openbare debat vining gepolariseer geraak het in twee kampe, naamlik diegene wat die beelde woul beskerm en diegene wat hulle wou vernietig, is die argument wat aangevoer word in hierdie artikel dat nie een van die opsies voldoende handel met die veelvuldige betekenisse van beelde nie. Deur ' $n$ ondersoek te doen na die veranderende diskoerse oor openbare geskiedenis in die 2oste eeu stel ons ' $n$ derde benadering voor, wat ingebed is in post-humanistiese argumente oor die beperkinge van kritiek en die moontlikhede van sorg as ' $n$ etiese, affektiewe en praktiese benadering. Ons argumenteer naamlik dat die post-humanistiese benadering tot wat mens moet doen met beelde in Suid-Afrika is om hulle te omvorm van fetisjistiese voorwerpe wat aanstoot gee of van erfenisvoorwerpe tot plekke waar nuwe publieke kan vergader en waardeur die historiese ontologie van kontemporêre magsdinamiek benader, ondersoek en oor gehandel kan word om nuwe vorme van burgerskap te bou.

SLEUTELWOORDE: Fetisj, post-humanisme, erfenis, beelde, publiek, Rhodes must fall. 
In South Africa the practice of toppling statues is as old as the practice of erecting them. The opening act of this now highly public symbolic battle took place when indigenous South Africans toppled the first monument erected on South African soil - the stone cross erected by Vasco da Gama in 1497 (Marschall, 2010:19). Da Gama responded with cannon fire, and the rest, as they say, is history. In this history the cannons prevailed so that by the end of the $20^{\text {th }}$ century there were around 3500 declared heritage sites in South Africa (Marschall, 2010:21).

The bulk of these were examples of colonial British and Cape Dutch architecture and sites associated with the Afrikaner struggle for self-determination. By 1992, 97\% of declared national monuments related to the values and experiences of the white minority. The National Monuments Act of 1969 provided no protection for the heritage of living communities because it inherited a focus on architecture, prehistoric and archaeological sites and artefacts from the earlier Relics Act of 1934 (Meskell \& Scheemeyer, 2008: 155). Archaeological sites in South Africa, however, fell outside the apartheid historical narrative. As the fate of the Mapangubwe golden rhino illustrates, much of the Iron Age history of SA could not be publicly recognized as heritage because it directly contradicted the myth that black South Africans arrived in SA at around the same time as the whites. Rock art sites, therefore, took up most of the remaining $3 \%$.

Stuart Hall (2005:24) describes heritage as "the material embodiment of the spirit of the nation" because in the British tradition that South Africa inherited, artefacts are only authorized as valuable enough to declare as heritage when they fit into the unfolding of an official national story. This skewed heritage landscape was, thus, the result of two things: the first, ideological, relating to the authorized national story; the second, practical, relating to a privileging of tangible heritage.

On the side of practice, South Africa's skewed heritage landscape is the result of two practical features of heritage. The first, mentioned above, is the inherited British privileging of material objects of artistic, archaeological or architectural significance (Marschall, 2010:21). The second is what Depelchin (2005:123) has termed the "syndrome of discovery". The term describes the dominant trend in the production of African history by outsiders. In this mode, truths are discovered according to rules of evidence deriving from broader relations of domination in disciplines that "deal with social reality from the perspective of the dominant group".

While South Africa might have new stories to tell, heritage practices have been resistant to the telling. On this front, we argue that the experiences in Eastern Europe give only scant suggestions as to how to approach symbolic landscapes, as we need a different mode for imagining our past. We will argue that the 2015 statue politics offer some useful clues for how to begin thinking about the practical aspect of building symbolic landscapes able to meet what Rassool has suggested is the primary challenge of public history, to enable new forms of citizenship (2000:1, 2010:96).
Rassool's point has much in common with Latour's (2004) suggestion that we replace "matters of fact" with "matters of concern". The former, he suggests are arrived at by using such tools as the "syndrome of discovery" to cut away reality until all that remains is a quite unreal and disconnected object called a fact. As Rassool (2010:83) shows in his criticism of Van Onselen's Kas Maine biography, the syndrome of discovery leads to the reality of Kas Maine's experiences being cut away until all that remains is an historically verifiable set of facts that can stand as "the remembrance of real collective experience".

On the side of ideology, in 1910, the newly formed South African Union was, to borrow the phrase from Meskell and Scheermeyer (2008: 153), a "state in search of a nation". In that context, heritage emerged as a national project and "key component of Afrikaner cultural rightist nationalism" (Shepherd \& Murray, 2007:4). Witz (1999 \& 2003) has slightly complicated this picture arguing that two large festivals illustrate two tendencies within this early 2oth century project of discovering a nation for what would become the apartheid state. The first festival focused on the production of an Afrikaner "volk" imaginary by constructing and commemorating the shared experience of the great trek. The 1938 Great Trek Festival left a trail of monuments scattered across the country and culminated in the laying of the Voortrekker Monument's foundation stone in Pretoria. It is at this culmination of the trek festival that the central character of this paper, Totius, makes his first appearance.

In The Rise of Afrikanerdom, Dunbar Moodie (1975) locates the origins of the "sacred history" of Afrikaner nationalism in Boer suffering during the South African war, as exemplified in the unveiling of the Women's Monument in Bloemfontein in 1913. During the late 1930 s and early 1940s, however, that "sacred history" was pushed back in time and the Great Trek was reenvisaged as the act from which Afrikanerdom was born. The 1938 Great Trek festival was central to this re-envisaged national cosmology and Totius (J.D. du Toit), Langenhoven and D.F. Malherbe were the central figures who, in speeches at the festival's culmination established "the intimate theological connection" between the Great Trek and the epic origin of Afrikanerdom (Moodie,1975:19).

Prior to the centenary festival, Afrikaners had been politically divided. The symbolic second trek, culminating in an event attended by 100 ooo people at the site of the Voortrekker monument contributed greatly to uniting Afrikaners around a mythical origin narrative. After the Eeufees celebrations, the Afrikaner Broederbond organized a second public meeting at the site of the Voortrekker monument. More than 70000 people attended and Van Rooy presented the main speech celebrating how the second symbolic great trek had unified the volk. Totius was once again a central figure and read a declaration calling for a renewal of the covenant.

In this solemn hour in which the air about us quivers with emotion, in which the raiment of praise replaces an anxious spirit, in which a holy fire spatters its sparks from soul to soul, we stand where less than a year ago we stood bound together as a nation. Now, however, we have not only a wish in our heart, but 
the very deed of volkseenheid [ethnic solidarity] before our eyes. In this hour, in which we acknowledge and confess with inexpressible gratitude that God alone is the Awakener of our nation, we wish to declare that the God of our fathers gave us righteous decrees and trustworthy laws, but we must also acknowledge that we as a People have departed from them with the result that we have one and all not only neglected our high ethnic calling but also quarrelled with one another. We wish with this declaration to reveal our desire and seal our longing constructively ... to serve our People. We grasp one another's hand on the Path of South Africa, never again to let go. This we declare solemnly by raising our hands (Moodie, 1975:194, emphasis added).

During the 1940s, Totius remained a leading figure in the construction of what Moodie refers to as Afrikaner civil religion. This religion was based on moving the cosmology of Afrikanderdom back from the Boer suffering at the hands of the British during the South African War to the Great Trek. It was the work of nationalistic intellectuals like Totius that transformed the Trek into a divine exodus by reframing it in biblical terms. Leaving aside such motivating factors as the change in legislation pertaining to slavery, Totius framed the Trek as answering the volk's "high ethnic calling". Re-casting the Trek as a divine calling enabled the producers of Afrikaner civil religion to liken the volk they were working to create with the Israelites, and frame them as God's chosen people.

Leaving the Cape was thus cast as fulfilling a "high ethnic calling", and the contested stories of the Trek were replaced by a monolithic factually informed narrative solidified in the beautifully chiselled stone panels of the Voortrekker Monument and reproduced in History textbooks. The story of the Great Trek, then, was the story of a volk that left the Cape because God had called them to do so. The men who left, and took with them their wives, children and slaves were recast as pioneers answering a divine call to bring light to the "dark morass", and in doing so fulfil their "high ethnic calling".

Motivated by the need to consolidate political power in an electoral base broader that the divine ethnic solidarity Totius was central in constructing, the second festival worked to establish a shared white settler identity beyond the Brit/ Boer division. The Van Riebeeck Festival in 1952, therefore, shifted the focus of public historical commemoration away from ethnic concerns and consciously attempted to craft a shared white identity by inaugurating Jan Van Riebeeck as the civilizing founder of modern South Africa (Witz, 1999:188). Both of these tendencies proceeded according to what Rassool (2010:96) has called the "syndrome of discovery". In both cases, a set of concerns, first the concern with uniting the Afrikaner volk, second the concern with creating a shared white identity animated the cutting away of reality to discover the facts. As Latour (2004:247) reminds us, "all matters of fact require, in order to exist, a bewildering variety of matters of concern".

Statues and monuments have widely been approached as "key elements of cultural landscapes linked to the political inscription of public space" (Light \& Young, 2011: 493). The 3500 heritage sites declared before the end of apartheid can thus be argued to be centrally important in the cementing of the narrative that Totius was so central in contriving. Thotse (2010: 174) has, for example, argued that the city text is a symbolic battleground for political control over space in the post apartheid context.

It is, therefore, not surprising that the dominant mode of engaging with the question of what to do with statues has been a textual approach - reading them as symbolic objects legitimizing a hegemonic order. We argue, differently, that while this textual approach cannot be ignored, it is a limiting frame. It cannot be ignored because it reveals underlying power relations, but it is limiting because it fails to admit the reality of those connections by making itself guilty of the same critical gestures that characterize the "syndrome of discovery". It makes itself guilty of this by unfolding according to what Latour (2004: 237) identifies as the association of criticism with anti-fetishism in terms of which the critic's role becomes that of showing that "what naïve believers are doing with objects is simply a projection of their wishes onto a material entity that does nothing all by itself". So the dispute gets stuck in the realm of competing fact/fetish claims.

According to the textual approach we are trying to move away from, building a new political order requires inculcating in a population a new historical narrative that legitimizes present distributions of power. As such, transformed political circumstances, particularly in the wake of totalitarian regimes, affect the lives statues lead. The official symbolic landscape onto which the values of the ousted political order have been projected and given stability must be removed when the time comes to imagine community differently. And there are numerous international examples of this.

On 17 March 2005, three decades after his death, the seven metre tall statue of Franco was removed from a Madrid square it had dominated since 1959. At the time of the removal, which began at 2am, "A small neo-fascist group protested against the removal of the statue while an even smaller group of supporters of the action cheered on" (Hadzelek, 2012:159). The removal itself passed without much concern. As the following day wore on, however, the absent statue gathered around itself a passionate public.

Falange, the Fascist party once headed by Franco, rallied 700 people to a protest at the site. People adorned the now empty plinth with flowers and flags, the international news media covered these proceedings and the quiet removal, kept secret even from city officials, erupted into a national debate about memory and commemoration. On one side of the debate was the position that the statue was shameful and ought to have been removed. On the other was the position maintaining that the removal would reopen wounds long healed (Hadzelek, 2012:160). This debate was significant in that it breached an agreement that prevailed in Spain after the transition to democracy. Political organizations agreed to refrain from using historical conflicts in their party politics and citizens were asked to keep their traumatic experiences 
out of the public realm (Hadzelek, 2012: 163). This agreement, reinforced by amnesty legislation, produced a national amnesia against the backdrop that attempts at justice or reparations would spark retribution.

The pact of silence in the Spanish case above contrasts somewhat with South Africa's Truth and Reconciliation Commission. However, in the South African case it was not a pact of silence that introduced amnesia, it was a mode of imagining the past. We are talking about the transformation of history into multicultural heritage, with an emphasis on healing. To be sure, we do not want to take all of heritage under a single umbrella and take note that "heritage can be seen as an assemblage of arenas and activities of history-making that is as disputatious as the claims made about the character of academic history" (Rassool, 2000:5). But in apartheid's wake, the past came to be "imbued with seemingly therapeutic powers that claimed to heal the state and its citizens economically, socially, and spiritually" (Meskell, 2012:2). We will argue that care, as articulated by Haraway (2003) and Puig (2012) might productively replace the emphasis on healing.

Heritage imagined as a unifying therapy, of course, has a history. Beginning in the late 1980s, repressing inconvenient historical details to celebrate South African multiculturalism in order to heal a divided nation began emerging as what Rassool (2000) would later describe as the dominant set of discourses through which to read the nation and its history. Critically, the healing and the wound to be healed were imagined to exist in the realm of symbol. Rassool (2010:96) has strongly criticized how heritage unfolded in many instances according to the "syndrome of discovery", thereby disabling what he saw as public history's primary challenge, that of enabling new forms of citizenship. Witz (2003) identifies this set of discourses as the third major public historical tendency in the $20^{\text {th }}$ century. As the project of dismantling apartheid began to take meaningful shape, the National Party orchestrated the clearest example of this turning towards a new 'multicultural' public history, the 1988 Dias festival commemorating the $500^{\text {th }}$ year since Dias first rounded the Cape en route to the East (Witz, 2006:162-163).

Dias literally fired the first killing shot in the history of colonial violence that would follow in his ship's wake (Witz, 2006: 178). This inconvenient detail was written out of the festival pageantry in favour of a programme celebrating cultural diversity with performances of Italian and Indian dancers alongside gumboot dancers and a Malay choir (Witz, 2006: 172). The 1988 celebration of Portuguese exploration is perhaps the proto example of the colours of the rainbow concealing, for the purposes of healing, the violence and inequality underpinning South Africa's oppressive multiculturalism. Multicultural heritage as a mode of public history, then, was from its official beginnings, as Meskell and Scheermire (2008:154) assert, more concerned with national performance than with social justice.

Multiculturalism here became a fit-for-purpose reconciliatory trope that enabled a celebration of the diacritics of South Africa's ethnic diversity but that foreclosed on the possibility of engaging with the interdependent relations of power and domination that linked these diverse categories into an unequal society. Indeed, so fraught were the relations between these groups at the time of the festival, that to colour it anything other than exclusively white, whites had to paint themselves black to perform the first multicultural contact between Europe and indigenous South Africans. History performed on the multiculturalist stage according to a Nationalist script, as a pageant of contact between categories imagined as largely separate and distinct, was an indication of things to come.

Meskell and Scheermeyer (2008:154) have argued that this heritage mode has assigned the past to a "precarious limbo" as all manner of stakeholders struggle to transform it into an object that can be mobilized in service of such goods as empowerment, restitution or social justice. Missing from their account, however, is how this precarious limbo was also filled with those who would try to mobilize the past in service of preserving their privilege.

When the end of apartheid failed to revitalize academic history in the way that many imagined might follow the collapse of the apartheid metanarrative and student numbers began dropping, history as an academic discipline turned to heritage for its therapeutic powers. It was in this moment, after witnessing Johan Marnitz's 1998 heritage day account of Afrikaners' fight against British domination that Jane Carruthers (1998) raised a concern that heritage offered a serious challenge to professional history. Heritage may well have opened the door for some new stories in terms of which citizenship could be asserted, empowerment and restitution sought and social justice served, but it also enabled the transformation of the apartheid mythology into cultural heritage as a post critical fact that could continue to enliven Totius' "high ethnic calling".

In 2014 Tokolos Stencils, a Cape Town-based group of graffiti activists responded to this preservation of privilege by spraying the words 'Disown this heritage' in red across the base of Cape Town's Paul Kruger Statue. The point that they were trying to make was that while statues of Kruger and other colonial figures might represent white South Africans' heritage, South African racial inequality is rooted in the order these figures represent.

One way of understanding why white South Africans should consider disowning this heritage is colonial sovereignty's relationship to violence (Mbembe, 2001:25). Mbembe specifies three types of violence upon which colonial sovereignty rests. The first and most obvious is the direct violence of conquest. The second is the violence of legitimation in terms of which conquest and colonial rule are rendered legitimate. The third is reiterative violence by which the colonized is daily reminded of his or her position as conquered and subordinate. We would add, drawing from Feldman (1994), the violence of omission, perhaps a type of legitimating violence, omission, such as writing Dias's killing shot out of the 1988 festival, legitimizes the status quo by writing out the violent interdependencies upon which it is contingent. In the spaces of everyday life it is particularly the racism of reiterative violence that inflicts the colonial wound that Mignolo (2005:8) argues defines Fanon's wretched of the earth. It is this violence that "gave the natives a 
clear notion of themselves in proportion to the power they had lost" (Mbembe, 2001:26).

Within this understanding of colonial sovereignty, the symbolic landscape does the work of legitimation and reiteration while the heritage modality does the work of omission. By violently assigning the standards of classification, violently assigning themselves the right to classify and violently asserting the power to name the world accordingly, colonial governments were able to write into the landscape a narrative of civilization and position colonized people within that narrative. In the context of colonial sovereignty the nationalist narrative of a "high ethnic calling" rendered as heritage obscures the interdependencies defined by the matrix of power that Quijano (2007), Mignolo (2007 and 2009) and Escobar (2007) term coloniality.

As Mignolo (2007) argues, colonial accumulation depended on direct violence. The primitive accumulation that characterized colonial capitalism required disposable labour, and disposability relied on the production of a categorical system in terms of which disposable life could be legitimized. Colonialism, and the capitalist systems it enacted required racism. Legitimizing these classificatory schemes fell to colonial intellectuals who crafted a hierarchical categorical system that transformed geographic diversity into the temporal continuity we know as "progress". Europe's Others were not simply different, they were backward; living artefacts of Europe's own past. Through this act of containing the diversity of the world in the narrative of progress, a matrix in terms of which human value could be distributed and justified was established. The political economy of this process in South Africa has been dealt with by Wolpe (1972) and Magubane (1979) among others and the central role of ethnic subjectivity in legitimizing this political economy has been discussed by Comaroff and Comaroff (1997) and by David Bunn (2001).

Putting Mbembe and Mignolo together we can argue that statues etching a colonial narrative into the past should go and the world should be renamed because every statue and street name, every mountain range and river named by the conquerors enacts the colonial wound; reminds native people of their position in the colonial matrix of power; leads them to know themselves in proportion to what they have lost. So a statue of Rhodes reiterates the work of the magnate in entrenching and profiting from colonial violence in South Africa. The statue also legitimizes that conquest by subverting its horrors under the general good of economic progress. Rhodes was central to building a Southern African economy and Southern African states. He is a true hero of progress. But as the massacre of mine-workers in Marikana illustrated, violence and super-exploitation via a migrant political economy ${ }^{1}$ has far outlived Rhodes.

$1 \quad$ According to Wolpe (1972) and Magubane (1979) South Africa's homeland system subordinated the pre-capitalist economy into the capitalist economy to create a single economic system in which the subordinated pre-capitalist economy subsidized the costs of reproducing the labour force thereby enabling lower wages. South Africa's capitalist mode of production was, thus, founded upon "the
Bauman (2007:6-7) has argued that the divorce between politics and power produced a condition of negative globalization. What he means by this is that the ability of political institutions such as parliaments to direct what happens in the world has been radically diminished as capital, people and information increasingly straddle state borders. Representational institutions such as parliaments are increasingly incapable of dealing with citizens' concerns inasmuch as these have come to span the globe in quite hybrid ways. Were the police at Marikana acting for London-based Lonmin, or in the interests of South African citizens? Speaking of the resulting ambience of uncertainty, Latour makes the point that in representational democracies we have all become politically disabled.

Totius's arrival on and departure from the Potchefstroom Campus affords the opportunity to ask if statues might, in the context of our political disability serve as political prostheses. In 2009 a statue of the Afrikaner poet and theologian, Jacob Daniel du Toit, better known as Totius, was relocated onto the Potchefstroom Campus of the North-West University from its isolated and neglected site alongside one of Potchefstroom's public roads. A statue of a central figure in the creation of Afrikaner civil religion, of course exercises a legitimizing and reiterative function vis-à-vis apartheid.

The idea to erect a Totius statue came from the Junior Rapportryers in the late 1960s. In 1972 a Totius committee was formally established in Potchefstroom under the chairmanship of Prof Tjaart van der Walt, the then rector of the Reformed Theological School of the Potchefstroom University. The committee's task was to plan events and memorials in preparation for the 1977 centenary of Totius's birth. The committee planned a museum, a commemorative garden and a monument. For the museum, the rector's residence in Molen Street was to be restored and converted into what is today the Totius House Museum. Establishing the Totius commemorative garden required convincing the Town Council to do extensive groundworks and install an irrigation system in preparation for planting trees and plants featured in Totius's poetry. The site was chosen because it was within walking distance of the rector's residence and because Totius spent time walking and fishing there.

The committee envisaged that the commemorative garden would serve as a backdrop for the planned monument and statue for which they had started raising funds. The Potchefstroom Herald of Friday 4 June 1971 outlined the plans for the Totius commemorative garden, showing how work towards the Totius festival had started prior to the formal creation of a committee. The article reported that the costs for the project would be in the order of R100 000 with annual maintenance costs of between R10 000 and R12 000. Creating the commemorative 
garden required laying underground drainage pipes, sinking a borehole to water the garden, and planting an extensive lawn. Establishing the Totius memorial garden therefore required buy-in, investment and long-term commitment from local council, as the garden's aim to commemorate Totius, and to serve as a pleasant and attractive public space demanded regular and costly maintenance.

In February 1977 Mrs Rupert officially opened the Totius House Museum. On the same day a pageant involving local schoolchildren and soldiers from the Potchefstroom military base culminated with Prime Minister Advocate B.J. Vorster unveiling the Totius statue. By the time we moved to Potchefstroom in 2005 the Totius commemorative garden had become a veld criss-crossed by informal footpaths marking it a transitory space of shortcuts. The 'veld by the Wasgoedspruit' was not a place where people lingered to relax or retreat as they might in a public garden. Gone were the almost one hundred trees planted by schoolchildren and students in August 1973 (Volksblad, 24 August 1973). There was no remaining evidence of the expensive irrigation system and infrastructure installed at the site in the 1970s. Under a democratic dispensation the site had changed from the sacred garden for the Adam of Afrikaner civil religion, into the neglected wilderness of a fall from grace.

Years before, in an effort to come to terms with campus politics after our arrival in the NWU's Anthropology subject group, we had read Theuns Eloff's short book about race and reconciliation. From it, and other sources we learned that Totius was the theologian who had argued the divine justification for racial segregation in a speech at the 1944 volkskongres, which met to discuss Afrikaner racial policy.

As a prolific poet and ideologue he played an important role in constructing Afrikaner ethnicity as a divine calling. As a theologian, however, he led the biblical justification for apartheid, through reading the bible according to what Snyman (2009:9) characterises as objectivist orthodox theology. Totius opened his 1944 speech with the following:

'Give me a Bible text,' says the opponent of our colour policy, 'a text that proves that segregation is in agreement with the utterances of Holy Scripture.' 'I have no text,' is my answer. 'Then I have won the case,' says the advocate for equality ... I answer: ... 'I don't have a text, but I have the Bible, the whole Bible. My argumentation would proceed from Genesis to Revelation (Volsoo, 2015:196, translation of Totius's opening remarks at the 1944 Volkskongres at Bloemfontein on Race Policy).

Totius proceeded to draw on Geneses 1, to argue that God acts as the skeidingmaker (divider). God the 'great divider' separates light from dark, land from water, living creatures. In doing so Totius transformed the cosmology of Genesis into a divine justification for apartheid racial policy.

After coming to know Totius for his roles in limiting Afrikaner identity to a biblical expression and in biblically justifying apartheid segregation we opposed the introduction of the statue onto the Potchefstroom campus. To no effect we voiced this opposition on the then very active internal bulletin board service and in a passing conversation to the then campus rector Professor Combrink. We appealed to the university to disown this heritage.

The statue was erected outside the Faculty of Law and campus life proceeded without taking much note of the new addition. Making the best of a bad situation, we decided to honestly take ownership of this heritage. We immediately put Totius to work in our lectures on race and racism in South Africa. Our students could go and look at the man who worked to make racism divine. He was a useful bronze embodiment of the contingent history by which a particularly terrible construction of race was made. We took ownership by making him a concrete reminder that racism was not divinely ordained; that the racist social order was not 'normal' but normalized in part by his biblical justification.

Beyond anthropology lecture theatres the statue took on other changed meanings. He became the popular backdrop for graduation photos, largely due to his position alongside a fountain outside the campus's most picturesque building. In that way he was incorporated into a new 'tradition'. But many students had no idea who the statue represented. Informal polls in class revealed that many students thought the statue was of former ZAR President Pretorius. Others thought it a statue of Hendrik Verwoerd - in fact, a representative of the city council is rumoured to have told the NWU that the Verwoerd Statue was ready to be moved on the day that the statue was transported. It is not possible to suggest that the statue was simply representative of a hegemonic nationalist order on the campus - but it is no more possible to dismiss the reading of colonial statues offered above.

Totius's usefulness for teaching the contingency of South Africa's racist configuration was aided by a photo we took of an outsourced black worker cleaning bird shit off the statue. We used it to teach students that the South African modernity of which his statue is metonymic depended on exploitable labour and that his scientific work to justify racism as divine contributed to making some human life dispensable enough to legitimise that high degree of exploitation. The photo also allowed us to bring home to students the irony of South Africa's liberation - a liberation in which a racialised system of exploited labour still benefits racial inequality's architects. To put this into Mignolo's terms, Totius afforded a good opportunity to teach students how the rhetoric of modernity, the story of progress and prosperity, depends on the logic of coloniality. What Totius taught our students was that modernity's progress and abundance are inextricably woven into the logic that makes some bodies dispensable in service of the production upon which that abundance depends.

Science fiction author Neal Stephenson (1992), in his novel Snowcrash, points out the connection between shit and science. Both share skei, to cut or to split, as a root. Science, he suggests is the practice of cutting falsehood away from truth while shitting is the practice of splitting waste away from what is useful. There is deep irony attached to a precariously employed 
man scraping animal waste off the man whose scientific work included legitimising a classificatory order that made the cleaner's ancestors waste to be scraped off the shoulders of urban South Africa in a campaign of forced removals that confined them to townships and homelands. Totius's scientific work served the logic that made this man removable and dispensable in service of the rhetoric of a nationalist modernity that Totius's public intellectual work painted as as divinely ordained.

It was, therefore, unsurprising that the return of shit to a similar statue by a man occupying a position similar to our cleaner's in the prevailing racial order brought to light the logic underpinning South Africa's monumental rhetoric and propelled statues into the centre of a national controversy. Sculpted by Marion Walgate and unveiled in 1934, Rhodes had stared out over an increasingly violent and unequal Cape Town for almost a century (Makoni, 2015).

Chumani Maxwele's emptying a bucket of human faeces onto the Rhodes statue on the University of Cape Town's upper campus on 9 March 2015 and the ensuing media coverage of the Rhodes Must Fall Movement's successful campaign to remove Rhodes from UCT brought statues to the centre of a much broader discussion of the linkages between knowledge, the institutions that validate it and South Africa's racist heritage. Metaphorically, the waste produced by colonial and apartheidorder builders like Totius and Rhodes was dumped at the feet of Rhodes, of UCT and of universities in general. The abject could not longer be repressed and universities had, finally, to interrogate how knowledge's production and validation are linked to the production of dispensable life. In the public realm, the separation of fact from value could no longer be neatly disconnected from the production of value and waste.

Of course there were those who felt the need to take ownership of and defend this heritage. Sunette Bridges and Steve Hofmeyr were the vanguard of this defence. Bridges rather unconvincingly chained herself to one of the Church Square statues, sparking an avalanche of '50 shades of khaki' memes on social media. Hofmeyr delivered a speech on the importance of history to a true civilization, a simultaneous appeal to the syndrome of discovery and the evolutionist telos of modernity that cast any dissent as ignorant and regressive.

Faced with the comedy of the chaining, of Hofmeyr's penchant for malapropisms (his condemnation of the 'deflowering' of his heritage) and photos of their supporters smilingly holding their placards upside down on the front page of the Beeld newspaper it would be easy to level a critical gaze at this group and dismiss them as naïve fetishists projecting an ethnic fantasy onto a set of statues. One could argue, for example, that Hofmeyr's Freudian slip betrays his concern for the virginal purity of the fantasy constructed by men such as Totius. Under this gaze Hofmeyr could be read as an ethnic patriarch defending the fake facts of the nationalist mythology from being defiled by the real facts of colonial oppression. But to do so would be to slip into the fact/fetish dynamic that sees each side reduce the reality of the other.
But taking them at face value credits the omission of violent interdependencies in keeping with writing Dias's first shot out of the Dias festival. Taking them seriously produces heritage as something that, because it omits all the violence of colonial sovereignty, naturalises current social fault lines by attributing them to separate ethnically guided lines of development. Taking them seriously subsumes all heritage in the old narrative of separate development so that heritage itself reiterates the colonial wound articulated by the students calling for the removal of statues.

"As black students we are disgusted by the fact that this statue still stands here today as it is a symbol of white supremacy." (Chumani Maxwele, quoted in Makoni, 2015).

"Rhodes has been praised for donating this land to the university, building the South African economy and bringing 'civilisation' to this country. But for the majority of South Africans this is a false narrative; how can a coloniser donate land that was never his land in the first place?"

"The statue is a constant reminder for many black students of the position in society that black people have occupied due to hundreds of years of apartheid, racism, oppression and colonialism" (Rambina Mahapa, quoted in Makoni, 2015).

The heritage association of South Africa responded to the Rhodes statue controversy via Jacques Stoltz (2015), with an argument that attempted to reset the reconciliatory multicultural status quo.

Either way, the university (including the present students) cannot wish away its colonial roots no matter how hard it may try. Accepting the contested nature of its history - and allowing for multiple interpretations and voices - will in our view be the best option to follow.

If communities are offended by the statue (which we accept may be a completely legitimate view) the university should not attempt to expunge history - this is non-productive and futile, but reassesses its policy to ensure that its public space becomes more representative of today's democratic values. This would be constructive and progressive. That shouldn't be too difficult given the significant number of black public intellectuals our country - and UCT in particular - have produced (Stoltz, 2015).

Both of these positions aim to make the colonial wound invisible. One aims to remove the inscription altogether, the other aims to balance it with inscriptions celebrating 'black intellectuals', which is what was done with the introduction of Sol Plaatje on the Potchefstroom Campus. While such juxtaposition may appear to journalistically balance the ideological content of the space, the omission of the colonial violence linking these juxtaposed figures comes to define the space. The Heritage Association of South Africa's suggestion mirrors attempts (of which Ngugi was so critical) to decolonize the curriculum by 
inserting black authors into the canon according to unchanged aesthetic principles. The call to remove statues and the call to balance them are ideologically similar inasmuch as they only see statues as fetishes.

Zizek (1993:1) begins Tarrying with the Negative with the image of the Romanian flag waving after the fall of Ceausescu with the star, the symbol of the communist past cut out, leaving only a hole in the middle of the flag where the star used to be. He invokes this image to discuss the open situation, a situation in which one symbolic order has fallen and no new one has risen yet to take its place. One inscription has been removed and no new inscription has yet taken its place. Zizek is clearly operating in the textual metaphor.

To reposition statues of a colonial past as resources for a decolonial future, however, requires stepping outside of this symbolic universe of critique and fetish. For one thing, overlaying a new democratically patterned blanket of meaning over a city does little to reorder the task-scape of the city derived from the largely unchanged relations of production that derive from the colonial and apartheid eras. Task-scape is a productive way of thinking about urban space inasmuch as the urban landscape is the congealing, in statues, buildings, routes and places, of the productive, reproductive, subversive and disciplining activities that make up the task-scape

Treating the city as a text is tempting, but it would be bizarre to be able to read as a text of liberation an urban geography that continues to entrench urban segregation through not only the distribution of housing, but the privatization of segregation (Bremner, 2004) and the planning of transportation systems (Czegledy, 2004). In the face of such a stubborn geography a city text of changed street names and new statues hardly seems substantially decolonial.

Zizek stumbles into the limits of the textual approach when he goes on to say that the open situation he points to was a false one as the coup that produced it was staged and that the old political order had survived by casting off its symbolic clothing. We have suggested above that the Dias festival and the shift to multicultural 'heritage' it represents had a similar quality. We wish to shift the focus from the hole in the flag to what was made invisible by the arrival of the hole, namely the old state apparatus that had staged this coup. If we treat the symbolic order as a text comprised of signifiers charged with meaning by those holding power, what Ingold (2002: 22) calls 'cyphers', the hole in the flag can be celebrated as an open situation. But if we shift register and treat the symbolic order as a crime scene where statues are clues (Ingold, 2002:22), not inscriptions, the hole becomes missing evidence. But evidence of what?

The most common response to calls to remove statues was that people should focus on 'real' issues, like poverty, inequality, environmental problems, state corruption, crime and so on. This is obviously a logically bankrupt argument as it implies we suspend everything and focus on the 'real' issues while ignoring who gets to set up the list of 'real' issues. But to simply dismiss it as a bad argument is boring and misses a useful insight, namely that this response shows the potential latent in those moments when statues become visible as clues rather than cyphers.

The trouble with statues and memorials is that they tend to obscure, beneath their impressive solidity, the myriad connections they bare to past, present and future entanglements. They have been historically useful because of their impressively disconnected solidity. A disconnection that enabled statues to be symbolically charged so effectively.

Riding this electrical metaphor leads us to a suggestion. Anusas and Ingold (2015) begin their meditation on electricity with a straw man that is useful to our argument. They begin by charging, in the legal sense of the term, that electricity has made us dependent and ignorant. We flick switches without knowing where the electricity comes from or how it travels to us, and life grinds to a halt when the power goes out. This attitude to electricity mirrors the critical attitude that suggests modern life is a false construction out of symbols like statues, the removal of which will lead back to some sort of authentic existence.

Anusas and Ingold (2015) respond to this charge with the argument that electricity is not itself to blame; after all, electricity is an unavoidable fact in the world. What is to blame for the ignorance and dependence is the infrastructure that conceals myriad wires and circuits and cables and mining and transport and political corruption and engineering and so on that make up the materiality of the grid linking us to one another every time a switch is flipped. They conclude that we should focus on what is obscured, the wires and processes of generation and distribution rather than the electricity itself.

For Mignolo, decoloniality, the project of delinking the promise of modernity from the rhetoric of coloniality, requires building a decolonial political society. For Rassool, the challenge of public history is to enable new forms of citizenship in the aftermath of apartheid. Following Anusas and Ingold (2015) we suggest that approaching statues as metonymy rather than metaphor, as clue rather than cypher, empowers the kind of network thinking that decolonial public history requires. As such a programme of adding the reality of these connections to statues is a more promising avenue for enabling a new kind of citizenship than either the current heritage framework or their removal. The lost opportunity of the campaign to remove Rhodes from the UCT campus becomes evident when we see the statue was a point of entry into the link between modernity and coloniality. Removing the statue removed the point of entry without in the slightest affecting the link because the link does not require a statue. Totius' passing from his pedestal represents a similar loss. The statue was removed in the dead of night to protect it and to avoid controversy. A potential battleground was removed before the battle could get underway. And the link remained untouched. A battle was not won; a battleground was lost.

So the challenge before us is to figure out how we can use statues to render the infrastructure of power visible and afford opportunities to gather contemporary concerns around them in meaningful ways. The shift from metaphor to metonymy 
enables a shift from therapy to care. Heritage as therapy was grounded on the notion that trauma is located as a hole in the symbolic realm. By making room for hidden histories to emerge multicultural heritage offered a kind of talking cure.

Thom van Doorn (2014) draws together the work of Puig (2012) and Haraway (2003) to unfold an understanding of care that we argue can replace therapy as the work of heritage in post-apartheid South Africa. Puig (2012:197) develops the understanding that care is a threefold encounter with the world that is simultaneously "a vital affective state, an ethical obligation and a practical labour". As an affective state, to care is to be at stake in another. As an ethical obligation to care is to become subject to another, and as a practical labour caring requires actually doing something. But of course caring is a compromised practice and Puig is quick to point out violentcare where caring for some individuals translates to suffering and death for others. Care is grounded in the "inescapable troubles of interdependent existences". As we have argued above, heritage as we know it has as a central feature the omission of interdependence. Omitting the troubles of interdependence leaves us only with violent-care. Removing this statue here is good for them there but harmful to these here.

Donna Haraway (2003:36) has addressed this problematic by arguing that "caring means becoming subject to the unsettling obligation of curiosity, which requires knowing more at the end of the day than at the beginning." It is this curiosity that leads Haraway to ask, in her companion species manifesto, "Whom and what do I touch when I touch my dog?" and to conclude that touching "peppers its partners with attachment sites for world making". Statues have the potential to stand as monuments to the inescapable troubles of our interdependent existences and by transforming them from metaphor to metonymy they can become the maps of those interdependencies that might guide our curiosity, so that at the end of the day we know more about our mutual dependencies than we did at the beginning.

Statues and memorials can be sites that gather up and map the interdependencies of contemporary concerns and that can perhaps provoke public engagement with those concerns if their solidity is troubled enough that they provoke the question "Whom and what do I touch when I touch this statue?" This is quite literally a monumental challenge, but there is no shortage of artists, intellectuals and other potential contributors who can participate in transforming the controversy around statues into the vital agora for a country that is deeply in need of one vis-à-vis the spread of privatization and criminalization of the public arena.

\section{DECLARATION OF CONFLICTING INTERESTS}

The author(s) declared no potential conflicts of interest with respect to the research, authorship, and/or publication of this article.

\section{FUNDING}

The author(s) received no financial support for the research, authorship, and/or publication of this article.

\section{REFERENCE LIST}

Anusas, M. \& Ingold, T. 2015. 'The Charge against Electricity', Cultural Anthropology, 30 (4), 540-554.

Bauman, Z. 2007. Liquid Times: Living in an Age of Uncertainty. Cambridge: Polity Press.

Bond, P. 2007. 'Introduction: Two economies - or one system of superexploitation'. Africanus: Journal of Development Studies, 37(2), 1-21.

Bremner, L. 2004. 'Bounded Spaces: Demographic Anxieties in Post-apartheid Johannesburg', Social Identities: Journal for the Study of Race, Nation and Culture, 10(4), 455-468.

Bunn, D. 2001. 'Comaroff Country'. Interventions: International Journal of Postcolonial Studies, 3(1), 5-23.

Carruthers, J. (1998) October 20, 'Heritage and History', Africa Forum [Online], 20 Oct, Available: http://h-net.msu.edu/cgi-bin/logbrowse.pl?trx=vx\&list=h-africa\&month $=9810 \&$ week $=c \& m s g=s v 82$ DZpkATFzGc7zqbkFKA [5 Sept 2016].\&

Comaroff, J.L. \& Comaroff, J. 1997. Of Revelation and Revolution, Volume II, The Dialectics of Modernity on a South African Frontier, Chicago: University of Chicago Press.

Czegledy, A.P. 2004. 'Getting Around Town: Transportation and the built environment in post-apartheid South Africa'. City \& Society, 2, 63-92.

Depelchin, J. (2005) Silences in African History: Between the Syndromes of Discovery and Abolition, Dar es Salaam: Mbuki Na Nyoto Publishers.

Escobar, A. 2007. 'Worlds and Knowledges Otherwise'. Cultural Studies, 21 (2-3), 179-210.

Feldman, A. 1994. 'On Cultural Anesthesia: From Desert Storm to Rodney King'. American Ethnologist, 21(2), 404-418.

Hadzelek, A. 2012. 'Spain's "pact of silence" and the Removal of Franco's Statues', in Kirkby, D. (ed.) Past Law, Present Histories, Canberra: ANU E Press.

Hall, S. 2005. 'Whose Heritage? Un-settling "the Heritage", Re-imagining the Post-nation', in Litter, J. and Naidoo, R. (ed.) The Politics of Heritage: the Legacies of 'Race', London \& New York: Routledge.

Haraway, D. 2003. The Companion Species Manifesto: Dogs, People and Significant Otherness. Chicago: Prickly Paradigm Press.

Ingold, T. 2000. The Perception of the Environment: Essays in Livelihood, Dwelling and Skill. London: Routledge.

Latour, B. 2004. 'Why has Critique Run out of Steam? From Matters of Fact to Matters of Concern'. Critical Inquiry, 30(2), 225-248.

Light, D. \& Young, C. 2011. 'Socialist statuary as post-socialist hybrids: following the statues of Dr Petru Groza in Romania'. Journal of Historical Geography, 37, 493-501.

Magubane, B.M. 1979. The Political Economy of Race and Class in South Africa. London: Review Press.

Makoni, Munyaradzi. 2015. March 27, 'Student revolt against the statue of Cecil John Rhodes', University World News [Online], 27 Mar, Available: http://www. universityworldnews.com/article.php?story=20150326130155803 [3 Aug 2016].

Marschall, S. 2010. Landscape of Memory: Commemorative Monuments, Memorials and Public Statuary in Post-apartheid South Africa. Leiden \& Boston: Brill. 
Mbembe, A. 2001. On the Postcolony. Los Angeles: University of California Press.

Meskell, L. 2012. The Nature of Heritage: The New South Africa. Oxford: Wiley-Blackwell.

Meskell, L. \& Scheermeyer, C. 2008. 'Heritage as Therapy: Set Pieces from the New South Africa' Journal of Material Culture, 13(2), 153-173.

Mignolo, W.D. 2005. The Idea of Latin America. Oxford: Blackwell Publishing.

Mignolo, W.D. 2007. 'Delinking' Cultural Studies, 21(2-3), 449-514.

Mignolo, W.D. 2009. 'Coloniality: The Darker Side of Modernity', in S. Breitwieser, S. (ed) Modernologies: Contemporary artists researching modernity and modernism, Barcelona: Museu d'Art Contemporani de Barcelona, pp. 39-49.

Moodie, T.D. 1975. The Rise of Afrikanerdom: Power, Apartheid and the Afrikaner Civil Religion. Berkeley: University of California Press.

Puig de la Bellasca, M. 2012. "“Nothing Comes without its World": Thinking with Care'. The Sociological Review, 60(2), 197-216.

Quijano, A. 2007. 'Coloniality and Modernity/Rationality' Cultural Studies, 21(2-3) 168-178.

Rassool, C. 2000. 'The rise of heritage and the reconstitution of history in South Africa'. Kronos, 26, 1-21.

Rassool, C. 2010. 'Power, Knowledge and the Politics of Public Pasts'. African Studies, 69(1), 79-101.

Shepherd, N. \& Murray, N. 2007. 'Introduction:Space, Memory and Identity in the Post-apartheid City', in Murray, N., Shepherd, N. and Hall, M. (Eds) Desire Lines: Space, Memory and Identity in the Post-apartheid City. New York: Routledge.

Stephenson, N. 1992. Snowcrash. New York: Penguin.

Stoltz, J. 2015. October 28, 'History is not for the Sensitive - HASA comments on the Rhodes Statue Saga'. The Heritage Portal [Online], 28 Oct, Available: http://theheritageportal.co.za/article/history-not-sensitive-hasa-comments-rhodes-statue-saga [3 Aug 2016].

Thotse, M. 2010. 'Contesting names and statues: battles over the Louis Trichardt/ Makhado "city text" in Limpopo Province, South Africa'. Kronos, 36(1), 73-183.

Van Doorn, T. 2014. 'Care'. Environmental Humanities, 5, 291-294.

Vosloo, R.R. 2015. 'The Bible and the justification of apartheid in Reformed circles in the 1940s in South Africa: Some historical, hermeneutical and theological remarks'. Stellenbosch Theological Journal, 1(2), 195-215.

Witz, L. 1999. 'From Langa Market Hall and Rhodes' Estate to the Grand Parade and the Foreshore: Contesting Van Riebeeck's Cape Town'. Kronos, 25, 187206.

Witz, L. 2003. Apartheid's Festival: Contesting South Africa's National Pasts. Bloomington: Indiana University Press.

Witz, L. 2006. 'Eventless History at the End of Apartheid: The Making of the 1998 Dias Festival'. Kronos, 32, 162-191.

Wolpe H. 1972. 'Capitalism and cheap labour-power in South Africa: From segregation to apartheid'. Economy and Society, 1(4), 425-456.

Zizek, S. 1993. Tarrying with the Negative: Kant, Hegel and the Critique of Ideology. Durham: Duke University Press. 